\title{
Guillain-Barre syndrome as a paraneoplastic syndrome in a 17-year- old boy
}

\section{Zespół Guillain-Barre jako zespół paranowotworowy u 17-letniego chłopca}

\author{
Paweł Dryżałowski * (D), Elżbieta Sołowiej * (D), Damian Okruciński **iD, Sergiusz Jóźwiak * (DD) \\ * Department of Neurology and Pediatrics, Medical University of Warsaw, Poland \\ **Medical University of Warsaw, Poland \\ DOI:10.20966/chn.2020.58.463
}

\section{ABSTRACT}

Guillain-Barre syndrome (GBS) is an acute inflammatory polyneuropathy, characterised by progressive, symmetrical muscle weakness and sensory disorder due to autoimmunologic myelin nerve sheats and/or peripheral nerves axonal damage. The course of the disease in children is usually milder than in adults. The most common variant of GBS is acute inflammatory demyelinating polyneuropathy (AIDP).

GBS is a rare disorder with morbidity rate of $0,5-1,5 / 100000 /$ year, more often seen in males. The course of disease in children is usually milder than in adults. Early diagnosis and proper treatment enables complete recovery in $80 \%$ of cases, while approximately $10 \%$ of patients suffer from symptoms recurrence, mainly after infection. Almost 2/3 of GBS cases are preceded by upper respiratory or gastrointestinal infection. The emergence of antibodies in various mechanisms, which cross react with nerve sheats or axon antigens (through a phenomenon known as molecular mimicry), leads to development of the syndrome. Known triggers inducing GBS include viral and bacterial infections, injuries, surgery, bone marrow transplantation and rarely childhood vaccinations. In still rarer cases, GBS may develop in the course of paraneoplastic syndrome (PNS), and be the first symptom of an underlying neoplastic process.

Key words: Guillain-Barre syndrome, hodgkin lymphoma, paraneoplastic syndrome, polyneuropathy, demyelination

\section{STRESZCZENIE}

Zespół Guillain-Barre (GBS) jest ostrą zapalną polineuropatią, charakteryzującą się postępującym, symetrycznym osłabieniem mięśni i zaburzeniami czuciowymi, wynikającymi z autoimmunologicznego uszkodzenia osłonek mielinowych nerwów i/lub uszkodzenia aksonalnego nerwów obwodowych. Najczęstszym rodzajem GBS jest ostra zapalna polineuropatia demielinizacyjna (AIDP).

GBS to rzadkie schorzenie o wspótczynniku zachorowalności 0,51,5 / 100000 / rok, częściej obserwowane u mężczyzn. Przebieg choroby u dzieci jest zwykle łagodniejszy niż u dorosłych. Wczesna diagnoza i odpowiednie leczenie umożliwiają całkowite wyleczenie w $80 \%$ przypadków. Około $10 \%$ pacjentów cierpi na nawrót objawów, gtównie po zakażeniu. Wielu pacjentów skarży się na przetrwałe zmęczenie. Niewydolność oddechową obserwuje się u $10-20 \%$, a zgon występuje w 3-5\% wszystkich przypadków. Prawie 2/3 przypadków GBS poprzedzone jest infekcją górnych dróg oddechowych lub przewodu pokarmowego. Pojawienie się w różnych mechanizmach przeciwciat, które reagują krzyżowo z osłonkami nerwów lub antygenami aksonów (poprzez zjawisko zwane mimikrą molekularną), prowadzi do rozwoju zespołu. Pośród czynników wywołujących GBS, wymienić można te związane ze szczepieniami, urazami lub przeszczepem szpiku kostnego. GBS może być także zespołem paraneoplastycznym (PNS), często obserwowanym jako jako pierwszy objaw procesu nowotworowego.

\section{Słowa kluczowe:}

Zespół Guillain-Barre, chłoniak hodgkina, zespół paranowotworowy, polineuropatia, demielinizacja

\section{INTRODUCTION}

Guillain-Barre syndrome (GBS) is an acute inflammatory polyneuropathy characterised by progressive, symmetrical muscle weakness and sensory disorder due to autoimmunologic myelin nerve sheats and/or peripheral nerves axonal damage. The course of the disease in children is usually milder than in adults. The most common variant of GBS is acute inflammatory demyelinating polyneuropathy (AIDP) [1].

GBS is a rare disorder with morbidity rate of $0,5-$ $1,5 / 100000 /$ year, more often seen in males. The course of disease in children is usually milder than in adults. Early diagnosis and proper treatment enables complete recovery in $80 \%$ of cases, while approximately $10 \%$ of patients suffer from symptoms recurrence, mainly after infection. Many patients complain of persistent fatigue. Respiratory failure is observed in 10-20\% and death occurs in 3-5\% of all cases [2]. Almost 2/3 of GBS cases are preceded by upper respiratory or gastrointestinal infection. The emergence of antibodies in various mechanisms which cross react with nerve sheats or axon antigens (through a phenomenon known as molecular mimicry), leads to development of the syndrome [3]. Known triggers inducing GBS include viral and bacterial infections, injuries, surgery, bone marrow transplantation and, rarely, childhood vaccinations. In still rarer cases GBS may develop in the course of paraneoplastic syndrome (PNS) and be the first symptom of an underlying neoplastic process.

\section{CASE REPORT}

A 17- year-old boy was admitted to the Pediatric Neurology Clinic of the Medical University of Warsaw in No- 
vember 2017 with a chief complaint of progressive muscle weakness in the extremities, paresthesia, intrascapular pain; he had difficulty walking lifting items and writing.

Before the hospitalization he was treated in the outpatient clinic for an upper respiratory tract infection, receiving clarithromycin for 8 days. During the treatment he complained about one episode of pronounced headache without nausea or vomiting, and one episode of intense back pain waking him from sleep.

In physical examination he was circulatory and respiratory efficient without signs of infection, nor enlargement of peripheral nodes was present. Meningeal symptoms were negative. In neurological examination there was evident flaccid paralysis: generalized weakness of muscular strength, the patient walked with aid and was unable to walk on his toes and heels. In further neurological examination - areflexia in upper and lower limbs, loss of surface sensation in the lower limbs distal to the knees, intrascapular and fingertip pain was revealed. Profound sensation, cerebellar function and cranial nerves function remained intact.

In laboratory examination:

- Positive serology for Mycoplasma pneumoniae $\operatorname{IgM} 50,07(\mathrm{~N}<12,9 \mathrm{U} / \mathrm{ml}), \operatorname{IgG}-75,98(\mathrm{~N}<9,9$ $\mathrm{U} / \mathrm{ml})$

- Autoantibodies connected with paraneoplastic syndromes - onconeuronal antibodies - negative

- Lumbar puncture revealed in CSF: an albuminocytologic dissociation with $78 \mathrm{mg} / \mathrm{dL}$ of protein (normal $15-45 \mathrm{mg} / \mathrm{dL})$, Pandy's test positive (+), Cytosis 4 cells/ul (normal 0-10 cells/u), glucose and lactic acid normal.

- In MR examination of the spinal cord - thickening of the nerves of the spinal cone and cauda equina.

Figure 1. Thickening of the nerves of the spinal cone and the cauda equina seen in MR examination.

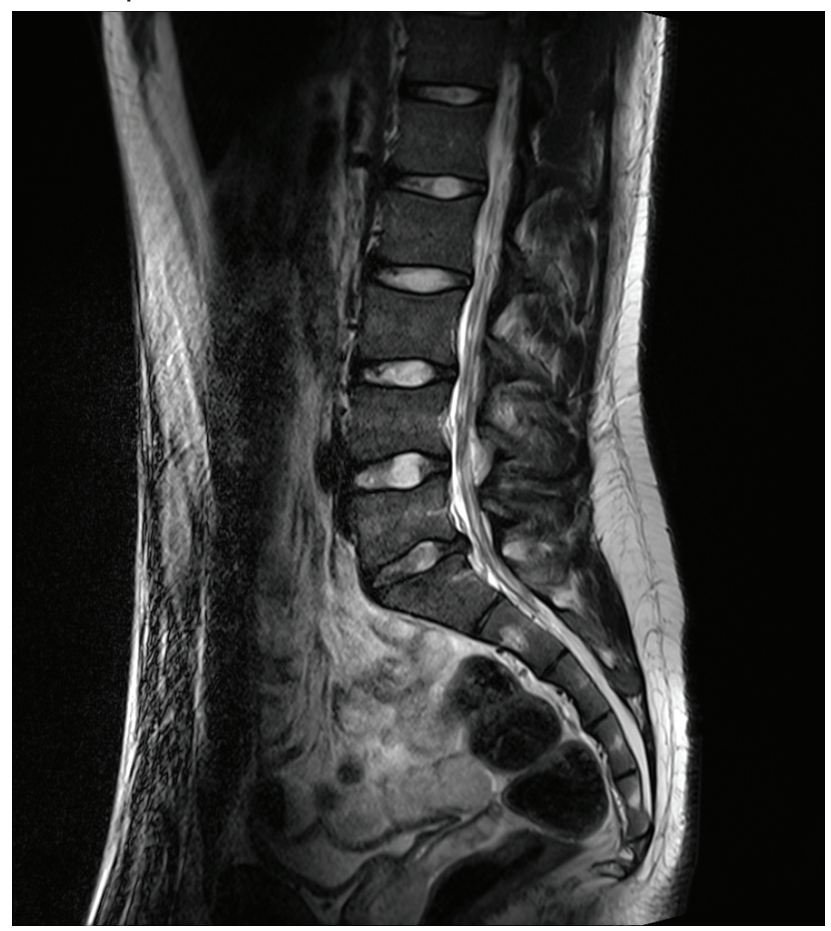

On account of the clinical picture and available laboratory tests the patient was diagnosed with GBS. IVIG (Kiovig) was given at $0.4 \mathrm{~g} / \mathrm{kg} / \mathrm{d}(40 \mathrm{~g})$ for 5 days, with significant improvement in muscle strength seen after two doses of Kiovig $40 \mathrm{~g}$ i.v.

In light of the history of upper respiratory infection, intra-scapular pain and persistent dry cough, a chest x-ray study was performed - the shadow of abnormal mass was described, approximately $42 \mathrm{~mm}$ in the mediastinum located on the right side, above the shadow of the lung cavity.

In the MR study of the chest - polycyclic mass, most likely numerous enlarged to $42 \times 27 \mathrm{~mm}$ lymph nodes in the upper mediastinum mainly on the right side surrounding the superior vena cava and the nameless right and the bracho-head stem, without signs of tracheal narrowing, in addition abnormal cervical lower / supraclavicular nodes especially on the left side .

Figure 2. Polycyclic mass, $42 \times 27 \mathrm{~mm}$ enlarged lymph nodes mainly in the right mediastinum

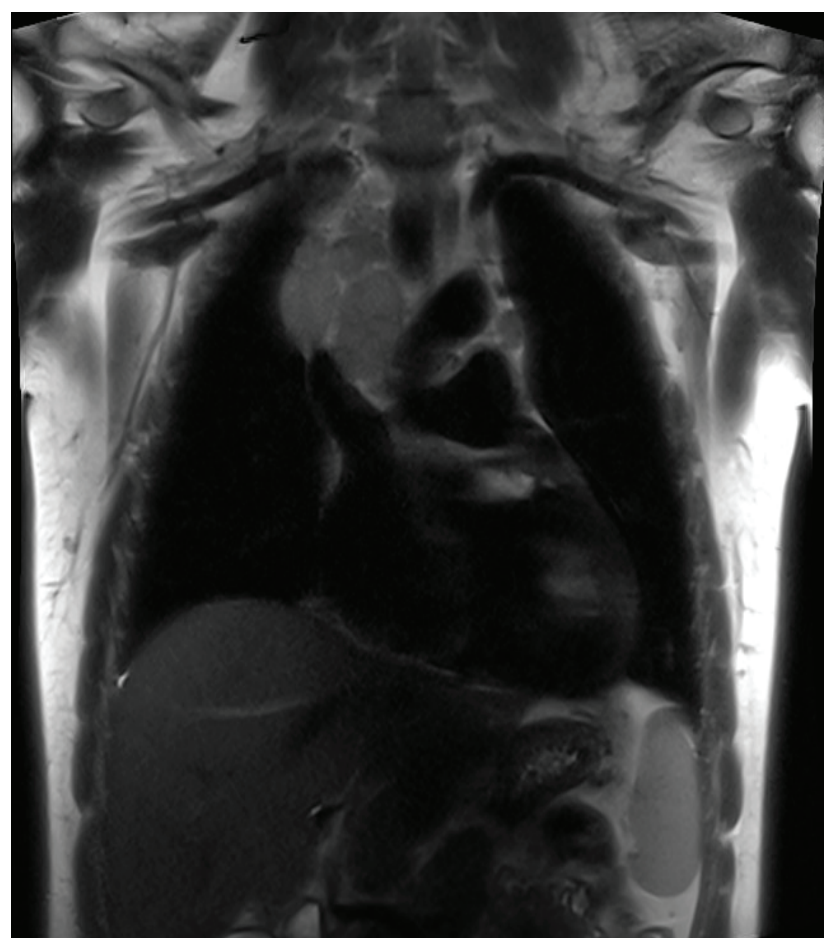

Suspecting a neoproliferative process, namely Hodgkin's lymphoma (HL), the patient was transferred to the Pediatric Oncology Clinic of the Medical University of Warsaw. Histopathological examination of the mediastinal lymph nodes confirmed typical features for Hodgkin's lymphoma. CT, PET-CT and USG examination confirmed diseased tissues above diaphragm, all summed by total approx. 250 $\mathrm{ml}$, without bone marrow and sub-diaphragmatic involvement, which led to diagnosis of stage IIA HL and qualified the patient to TG-2 therapeutic group.

Oncology treatment:

2 blocks of OEPA treatment (prednisone, vincristine, doxorubicin, etoposide) and 2 COPDAC blocks (prednisone, dacarbazine, vincristine, cyclophosphamide) were planned. 
- OEPA I block - complicated by hypertension, diarrhea of noroviral etiology, stomatitis, neutropenia.

- OEPA II block - complicated by herpes labialis, parotitis associated with parainfluenza, neutropenia.

- COPDAC I block - complicated by neutropenia and zoster.

- COPDAC II block - complicated by neutropenia and herpetic whitlow.

Cancer mass regression was seen after 2 OEPA blocks.

During chemotherapy worsening in general weakness was observed, in neurological examination areflexia in the upper and lower extremities, distal muscular atrophy, surface sensation disorder - features of polyneuropathy associated with vincristine. Post-steroid obesity was also an upcoming complication. Regression of mediastinal changes was reported at the end of

chemotherapy. After chemotherapy the patient was intensively rehabilitated, a gradual improvement in general fitness and muscle strength was observed, despite the peripheral nerve axonal damage found in the ENG / EMG study.

Patient was consulted by the Polish HL treatment coordinator who did not qualify him for radiation therapy. During treatment he reached adulthood and was transferred to further hematological care at the Medical University of Warsaw Clinical Hospital for adults.

There was resumption of the cancer process in the PET-CT check-up (October 2018).

\section{DISCUSSION}

The vast majority of GBS cases are preceded by upper respiratory tract infections or contaminated food intake. Viruses (influenza virus, CMV, EBV, herpes, chickenpox, Zika, HIV) and bacteria (Campylobacter jejuni, Mycoplasma pneumoniae, Haemophilus influenzae) are most common [2]. Two cases of GBS in association with COVID-19 infection have been described in literature recently $[4,5]$. GBS may also develop after trauma, severe stress, surgery, bone marrow transplantation vaccination (e.g. against influenza). GBS can also be diagnosed in association with paraneoplastic syndrome; be the first sign of cancer eg. Hodgkin's Lymphoma [6].

In this case etiology remains mysterious due to its complexity. Mycoplasma pneumoniae infection, confirmed by positive serological tests, should be taken into account in the differential diagnosis of the potential etiological factor of GBS. Scheduled neurographic examination had to be postponed due to the need for rapid diagnosis and initiation of oncological treatment, and was performed after the first cycle of chemotherapy. Results showed changes of demyelinating and axonal features. The interpretation should not ignore the possible neurotoxic effect of chemotherapeutic agents, including vincristine. Neurological symptoms experienced by the patient with HL may be the result of a direct tumor mass effect (nerve infiltration by a tumor - more likely in non-Hodgkin's lymphoma than HL), chemotherapy and its side effects (neuropathy associated with vincristine) or paraneoplastic syndromes (autoaggression) [7]. In past medical literature the isolated cases of atypical GBS course in patients with underlying HL, demonstrating no improvement post IVIG treatment, more so with worsening of the general state and increased pleocytosis in the general examination of the cerebrospinal fluid, may change the overall image of the disease and impede quick diagnosis $[8,9]$.

In the described case it seems reasonable to diagnose Guillain-Barre syndrome as a paraneoplastic syndrome in the course of Hodgkin's lymphoma. At the same time it cannot be excluded that Mycoplasma pneumoniae infection confirmed by positive serological tests was an additional etiological factor of GBS. The treatment of Guillain-Barre syndrome in diagnosed Hodgkin's lymphoma was extremely difficult due to many complications, as it was superimposed by chemotherapeutic treatment with neurotoxic effects. In addition, during the treatment the patient had several viral infections that additionally damaged nerves, including zoster.

\section{CONCLUSION:}

While searching for the etiology of GBS development, the clinician should take into account neoplastic processes as a possible underlying condition.

\section{REFERENCES:}

[1] Halstead S.K., Zitman F.M., Humphreys P.D., et al.: Eculizumab prevents anti-ganglioside antibody-mediated neuropathy in a murine model. Brain 2008; 131(Pt 5): 1197-1208.

[2] Hughes R.A., Cornblath D.R.: Guillain-Barré syndrome. Lancet 2005; 366: 1653-1666.

[3] Langmuir A.D., Bregman D.J., Kurland L.T., et al.: An epidemiologic and clinical evaluation of Guillain-Barré syndrome reported in association with the administration of swine influenza vaccines. Am J Epidemiol 1984; 119: 841-879.

[4] Sedaghat Z., Karimi N.: Guillain-Barré syndrome associated with COVID-19 infection: A case report. J Clin Neurosci 2020; 76: 233-235. doi:10.1016/.j.jocn.2020.04.062

[5] Virani A., Rabold E., Hanson T., et al.: Guillain-Barré Syndrome associated with SARS-CoV-2 infection. IDCases 2020; Apr 18: e00771. doi: 10.1016/.j.idcr.2020.e00771.

[6] Lisak R.P., Mitchell M., Zweiman B., et al.: Guillain-Barre syndrome and Hodgkin's disease: three cases with immunological studies. Ann Neurol 1977; 1: 72-78.

[7] Kelly J.J., Karcher D.S.: Lymphoma and peripheral neuropathy: a clinical review. Muscle Nerve 2005, 31: 301-313.

[8] Rauschka H., Jellinger K., Lassmann H., et al. Guillain-Barré syndrome with marked pleocytosis or a significant proportion of polymorphonuclear granulocytes in the cerebrospinal fluid: neuropathological investigation of five cases and review of differential diagnoses. Eur J Neurol. 2003 Sep; 10(5): 479-486. doi: 10.1046/j.1468-1331.2003.00644.x. PMID: 12940826. Csf

[9] Anderson D., Beecher G., Steve T.A., et al. Neurological Nuance: Hodgkin lymphoma presenting with Guillain-BarrÉ syndrome. Muscle Nerve. 2017 Apr;55(4): 601-604. doi: 10.1002/mus.25439. Epub 2016 Nov 9. PMID: 27756115. 